\title{
Miss Charlie by Suzanne Paradis: Subversion in Women's Writing
}

\author{
Christl Verduyn
}

Reading Suzanne Paradis' most recent novel-Miss Charlie - does not make at all clear precisely who Miss Charlie is. Indeed, one is even tempted to enquire: what is Miss Charlie? This perplexity is not simply a result of the fact that Miss Charlie is the highly complex protagonist of a complicated novel. The reader's uncertainty about the identity or purpose of Miss Charlie is also a function of the fact that the novel Miss Charlie has been designed to illustrate the potential of subversive writing.

This subversion unfolds within the relationship between the two main characters of the novel, Marie-Charles Craig-Miss Charlie - and an American writer, Gordon Mortimer. Mortimer represents the oppressiveness of established order; only a deeply authoritarian and arrogant, haughty and proud man could describe himself as "the illustrious author of nine psychological novels which have had the good fortune of pleasing several thousand Americans" (65). ${ }^{1}$ His character exerts a strange but compelling influence not only over his wife Gloria-Rose-whom he delights in humiliating in public-but also over the inhabitants of Montrose, Miss Charlie's small town 
community. Indeed, while Miss Charlie has been leading an apparently peaceful life in Montrose (being widowed after only six months of marriage), she is particularly susceptible to the powers of her new neighbour. From the day that Mortimer arrives in Montrose, Miss Charlie becomes aware of unsettling changes in herself:

That morning - just an ordinary June morning - something flashed in the mirror when I looked at myself in it. . I had just surreptiously changed souls or the one I was accustomed to had undergone an irreversible change. ... (13)

I approached myself as though through an intermediary, as if the look that was consuming me was no longer mine but that other one I had unconsciously refused for the last I2 years. Powerless, I watched the progressive crumbling of my daily surroundings. My behaviour already reflected the singular turmoil, the imperceptible derailing of my personality, which is the subject of this story.... (I4)

What signs revealed the metamorphosis I felt myself desperately undergoing. ... (I6)

The most intriguing development in Miss Charlie's life is that she then begins to write- but in secret. This possibility had always been latent in Miss Charlie's personality; that she had given over part of her huge house to a public library was a concrete manifestation of her interest in books. Mortimer was not unaware of Miss Charlie's interest in this regard for he asks her to translate his novel The Snowman from English to French. But could Mortimer have realized that this request would open a Pandora's Box? Writing would offer Miss Charlie three extraordinary resources: the tools of resistance, the means of subversion, and the route to her realization as a writer.

After Mortimer's arrival, the first task for Miss Charlie is to devise a means to resist his strange powers of control, for "Mortimer had metamorphosized our lives and would continue to upset them." (90) The American writer had settled down in Montrose to extract materials from the village annals which he would then process into his own writing. For Miss Charlie, this is an intolerable invasion of Mortimer's consciousness into "the closed garden of her soul" (IIO): "Because of him, I would be forced to halt a dangerous development 
and to confront events only partially understood."(90)

So, Miss Charlie decides to fight fire with fire. She herself determines to write, so that the American Mortimer will not have monopoly powers over the resources offered by writing. This previously exclusive right had given Mortimer alone the power to construct a universe, to process the inhabitants of Montrose into fictitious characters, thereby reconstructing their lives as inventions. By writing in her grey notebooks, Miss Charlie declares herself Mortimer's competitor, and his equal:

Did I not buy a typewriter in order to secure the corresponding right to his to re-invent life? (IOI)... I knew exactly... what I had to write and knowing it, I felt an indescribable relief. I was no longer this unintelligible woman whose thoughts and actions deviate from their own secret logic, who gets up one morning on the edge of despair, so dizzy she no longer recognizes herself. Did everything not happen in the most logical manner possible? (22)

Like Mortimer, then, she begins to write and, also like him, she appropriates little by little those elements of her surroundings which inspire her: "Every morning I write things which I am certain to think, which follow from the day and night, which usurp names that I should respect." (38) Thus, one night her imagination spins and whirls around her niece Chinchilla's boyfriend, with whom Miss Charlie has as bizarre as relationship as she has with Mortimer. She settles on the young man quite simply because "he constituted a sort of enigma, a point of interest not to be overlooked since the story had to take shape." (37) And, for Miss Charlie, the concrete realization of the story is what is most important. Thus, she does not deny herself the indulgent pleasure of speculating about the potential mysteries of her new neighbours; on the contrary, she forges ahead, and her strange writing transforms them, so that they acquire bizarrely "majestic proportions" (47): "I was unavoidably confronted with this unknown couple, about whom I could make up stories as long as the mysteries lasted." (43) In short, "no sooner observed than behaviour would find its explanation in her story." (39) Miss Charlie is very much aware of her inclination to appropriate every snippet of truth 
in order to enrich her writing: "it was literally as if all the events in the world were rushing in to the centre of the most peaceful little life that ever was, Marie-Charles Craig's." (SI)

However, Miss Charlie does not rest content in merely equalling Mortimer's appropriation of the Montrose surroundings. While she does incorporate this environment in the fictional world of her grey notebooks, she goes much further. Indeed, she goes beyond resisting Mortimer in her writing to actually subvert him, by appropriating the characters of Mortimer's novel as she goes about her translation. In order to prepare herself for this task of translation, Miss Charlie had read all of Mortimer's novels, an undertaking which overwhelmed and stunned her: "Mortimer hypnotized, he made you waltz on the brink of despair without allowing you to be afraid or to suffer." (67) But, if she is astounded by what she reads, Miss Charlie does not lose her wits:

I wanted to resist this delirium that I knew would confuse my own and take away its freedom. I struggled against Mortimer, at times with all the subtlety of which I was capable, other times by shouting, stamping my heels on the floor, savagely ripping up guilty pages. (67)

This subtlety which Miss Charlie devises is no less than the utter subversion of Mortimer's writing. She subverts his novel The Snowman, as she slyly reconstructs its meaning through her French translation, all the while substituting sentences, words and observations of her own. What is the purpose of this drastic alteration? In response to Mortimer's enquiries as to the progress of the translation, Miss Charlie muses:

How to admit to Mortimer the struggle I was enduring trying to prevent his novel from overshadowing my own? It would have been so easy to admit my project to him, to treat him like a friend rather than an enemy. But that was precisely the point: Mortimer's total enigma rested between us and my desire was not to break it open but to conquer it.

So, Miss Charlie's writing is not a project whereby she reaches an accomodation with Mortimer; rather, her writing offers the most 
subtle but subversive way of conquering him:

Was I translating the manuscript exactly or had I already begun to reconstruct, by meticulously altered stages, the secret framework?... I was disappearing. .. through a substitution which would bring others in its wake, countless substitutions in a flood of frightening confusion. Gordon Mortimer's secret universe was nothing. (IOO)

Later, we learn that this subtle subversion was crowned with success; the translation of The Snowman was never published, as a result of its not having been faithful enough to the original. Hence, Miss Charlie's original fear of being invaded by Mortimer has not come to pass; rather, it is Miss Charlie herself who has done the invading, by entering the realm of writing-a domain of authority which Mortimer had previously been able to reserve for himself. When Mortimer recognizes the success of Miss Charlie's invasion, he reacts with fury:

He was shouting accusations; everyone here told tales, there was a bluff every minute and everyone did it with glee. It was abusing his rights as a writer, it was encroaching on a territory he would defend with all the harshness necessary. Brusquely, he took some sheets of paper from his drawer and scattered them in my direction with a gesture that was both brutal and ingratiating. As they flew past I recognized my handwriting.

-Surely you understand, Miss Charlie. He spit the words out of his mouth. (169-70)

In reaction, Miss Charlie responds as if innocent of these charges:

How had these criminal pages managed to slip in among the pages of The Snowman? Had I unconsciously wished this confrontation? Anonymity must have been weighing upon me. (170)

Of course, Mortimer feels threatened by Miss Charlie's reincarnation as a writer, especially as a writer with a distinctly contrasting style. Ironically, it was he who had triggered this creative process which offered to transform Miss Charlie's life. (213) And, indeed, 
Miss Charlie undergoes considerable change. Gone is the soft-hearted widow, who had previously been proud of having never given in to any passion generated by ignorance or aggression. (II) This contented, complacent woman - whose self-image was of an empty tenderness and gentility (I2) - has been transformed into another being who now experiences all the doubts and agonies of the writer who hovers along the borderline between fiction and reality; she now searches restlessly for a kind of writing which experiences its very own laws:

I was transgressing reality to penetrate into the universe of lies and fiction. (I47)

... there were times when I wanted to escape, to truly escape all those constraints whose purpose is to mask reality. (33)

... I spirit away hateful appearances, and plunge into the chasm of fiction. (IOI)

I had decided to keep an eye on myself, to spy on myself in a sense, so as not to deviate from my own laws. (IOI)

Rejecting Mortimer's kind of writing, which accepted the lies of appearance, Miss Charlie's writing is characterized by a search for reality and truth which is obstructed by Mortimer's appearances and fictions. Moreover, the style and approach of Miss Charlie's writing transcends formal constraints like chronology, logic and plausibility: this search for truth behind appearances requires a freer form of writing uninhibited by formal constraints:

I never wanted my writing to reproduce every-day reality. On the contrary, I even wish a confusion which will shelter me from the most natural of indiscretions. (37)

I no longer really chose details; they surged forth in apparent disorder, furtively reaching otherwise forbidden spaces, shamelessly exploring the forbidden life. Presumed author of this story, I foresaw the escape of almost all the elements I had collected together, unfamiliar transactions at the level of reality and the imaginary. It was a feverish and singular game which brought me closer to Gordon Mortimer and strengthened me against him. (I48) 
In this, Miss Charlie does not disclaim that contradictions and implausibility abound in her writing; nor does she deny that she has sought to disconcert the reader and trouble his soul. (I2) For in the search for truth and reality, her writing must obey laws of a different nature, and these laws do not exclude the possibility of confusion and delirium. But delirium was something Mortimer had wanted to reserve for himself alone, just as he had wanted exclusive rights to be a writer: "It's a writer's job to be delirious, to manipulate human beings," Mortimer tells Miss Charlie in anger. "You do so without rights." (64) But this contention is futile, for Mortimer cannot refuse Miss Charlie access to delirium and the right to be a writer. Indeed, she has become a writer because of him and in spite of him. And in the process of becoming a writer, she has discovered herself: "From that point forward,I knew why I existed and because of this I knew a peace of soul that allowed me to get back on my feet again." (315)

The process of writing is Miss Charlie's triumph. This triumph has been accomplished by subverting the text of another writer, a male writer. So, when Mortimer announces the launching of his twenty-second novel-entitled Miss Charlie - we know that the true story of Miss Charlie has been told by Miss Charlie herself in the pages of the novel that Suzanne Paradis has placed in our hands.

Notes

${ }^{1}$ All translations are my own. Page references are to the original French text: Suzanne Paradis, Miss Charlie (Montréal, 1979). 